\title{
Dissolved organic carbon in North Atlantic surface waters
}

\author{
Paul E. Kepkay ${ }^{1}$, Mark L. Wells ${ }^{2}$ \\ ${ }^{1}$ Biological Oceanography Division, Department of Fisheries and Oceans, Bedford Institute of Oceanography, PO Box 1006, \\ Dartmouth, Nova Scotia, Canada B2Y 4A2 \\ ${ }^{2}$ Marine Research Division, 0220, Scripps Institution of Oceanography, La Jolla, California 92093, USA
}

\begin{abstract}
Dissolved organic carbon (DOC) was analyzed by high temperature catalytic oxidation at 3 stations in the North Atlantic. The stations were chosen to cover a range of environments in the mixed layer, from coastal water in Roseway Basin on the Scotian Shelf to water from the seaward edge of the Scotian Slope and finally to open ocean water in the western Sargasso Sea. At 2 of the stations (Roseway Basin and Slope), the DOC revealed in surface waters by high temperature catalytic oxidation appeared to be biologically labile. DOC was positively correlated with chlorophyll and inversely correlated with apparent oxygen utilization (AOU). An inverse relationship between DOC and AOU was also found in deep water from the open ocean. This was in agreement with results from earlier analyses, but the negative slope of DOC with AOU was less than expected from the previous measurements. A relatively simple picture of the lability of DOC in the mixed layer was not always apparent in Roseway Basin or the open ocean. Horizontal advection and biological patchiness in weakly stratified surface waters contributed to large day-to-day variations in the DOC profiles. This variability should be taken into account when DOC is included in models of carbon cycling in the upper ocean.
\end{abstract}

\section{INTRODUCTION}

The measurement of dissolved organic carbon (DOC) in seawater has been an ongoing problem for oceanographers (E. T. Peltzer et al. unpubl.). Accurate measurements of DOC are particularly important for constraining the mass balance of carbon in whole ocean models (Craig 1971, Jackson 1988, Toggweiler 1989) and for assessing the sensitivity of the ocean carbon cycle to climate change (Ducklow et al. 1989). Results from recent analytical developments in high temperature catalytic oxidation (Sugimura \& Suzuki 1988) suggest that oceanic DOC has been systematically underestimated by a factor of about 2 , or some $880 \times$ $19^{9}$ tonnes of organic carbon (Peltzer et al. unpubl.). This additional DOC could be a significant fraction of the world's carbon budget and lead to the revision of concepts based on the ratios established between carbon, nitrogen and phosphorus (Redfield 1958, Redfield et al. 1963). While major revisions of well-established concepts would be required (Jackson 1988), it is important to remember that the magnitude of DOC underestimation is still open to question. The analysis of DOC is currently the subject of vigorous debate (Hedges 1992) and a universally-accepted analytical technique has not been developed.

Implicit in the inclusion of DOC in a global carbon budget is the assumption that some fraction of this carbon is biologically labile (Williams \& Druffel 1988) and is respired to $\mathrm{CO}_{2}$. Yet DOC appears to be largely unreactive (Hedges 1987), despite the fact that it is equal to the amount of carbon stored in terrestial forests or soil humus. This conflict is made more severe by the possibility that high temperature catalytic oxidation reveals even more DOC than before, particularly in samples from the upper 50 to $200 \mathrm{~m}$ of the water column (Toggweiler 1990, Peltzer et al. unpubl.).

A partial answer to the conflict lies in observations that DOC degradation in the upper ocean can be accelerated by linked physical and microbial processes. For example, Johnson \& Kepkay (1992) showed that a colloidal fraction of DOC may escape bacterial degradation by virtue of its particle size characteristics. Only when this larger colloidal material is concentrated into aggregates by processes such as surface coagulation can it be more easily accessed by the bacteria and 
rapidly respired to $\mathrm{CO}_{2}$ (Kepkay \& Johnson 1989) However, the results from recent incubation experiments suggest that coagulation is not an absolute requirement for the rapid degradation of DOC. Kirchman et al. (1991) obtained the first direct evidence that microbiota in surface water from the open ocean break down the DOC measured by high temperature catalytic oxidation. They also found that rate constants for DOC degradation can be as high as $20 \% \mathrm{~d}^{-1}$

While these data suggest that DOC can be broken down rapidly in short-term incubations, an additional factor must be considered. When profiles of DOC measured by high temperature catalytic oxidation are compared with oxygen utilization profiles, there is often a correlation of DOC with apparent oxygen utilization (AOU). In both the Pacific (Sugimura \& Suzuki 1988) and Atlantic Oceans (Peltzer et al. unpubl.), DOC minima were observed in association with AOU maxima at the permanent thermocline (at a depth of about $1000 \mathrm{~m}$ ). In the words of Peltzer et al. (unpubl.). this relationship lays open the possibility that a fraction of the DOC pool is biologically labile and is rapidly cycled, in stark contrast to prevailing wisdom'. To date, DOC and AOU profiles have been presented together over a depth range of about 200 to $4000 \mathrm{~m}$ and may not have taken into account the recycling of DOC in the upper ocean. We focus here on the analysis of DOC by high temperature catalytic oxidation in the upper 100 $m$ of water at 3 stations in the North Atlantic. The objectives of our measurements were: (1) to determine if the inverse relationship between DOC and AOU holds true for the upper ocean; and (2) to determine if variations in DOC are associated with such standard biological parameters as the concentration of chlorophyll a.

\section{MATERIALS AND METHODS}

Seawater collection. In the first 3 wk of April 1991, seawater was collected during CSS 'Hudson' cruise 91001 as part of JGOFS (Joint Global Ocean Flux Study). Water was collected from a variety of depths in 81 PVC Niskin bottles on an 18-bottle rosette incorporating a CTD. Three drift stations (Fig. 1) were chosen for sampling to include a wide range of water types in the upper $100 \mathrm{~m}$. A coastal station was located in $147 \mathrm{~m}$ of water in the Roseway Basin on the southern flank of the Scotian Shelf, while a second station was located in $4000 \mathrm{~m}$ of water at the seaward edge of the Scotian Slope. A final, open ocean station (NFLUX) was located in the western Sargasso Sea in $4700 \mathrm{~m}$ of water; the biological and hydrographic characteristics of NFLUX during the late summer are described elsewhere (Longhurst et al. 1989, Kepkay et al. 1990). Shallow rosette casts (sampling the upper $100 \mathrm{~m}$ ) were

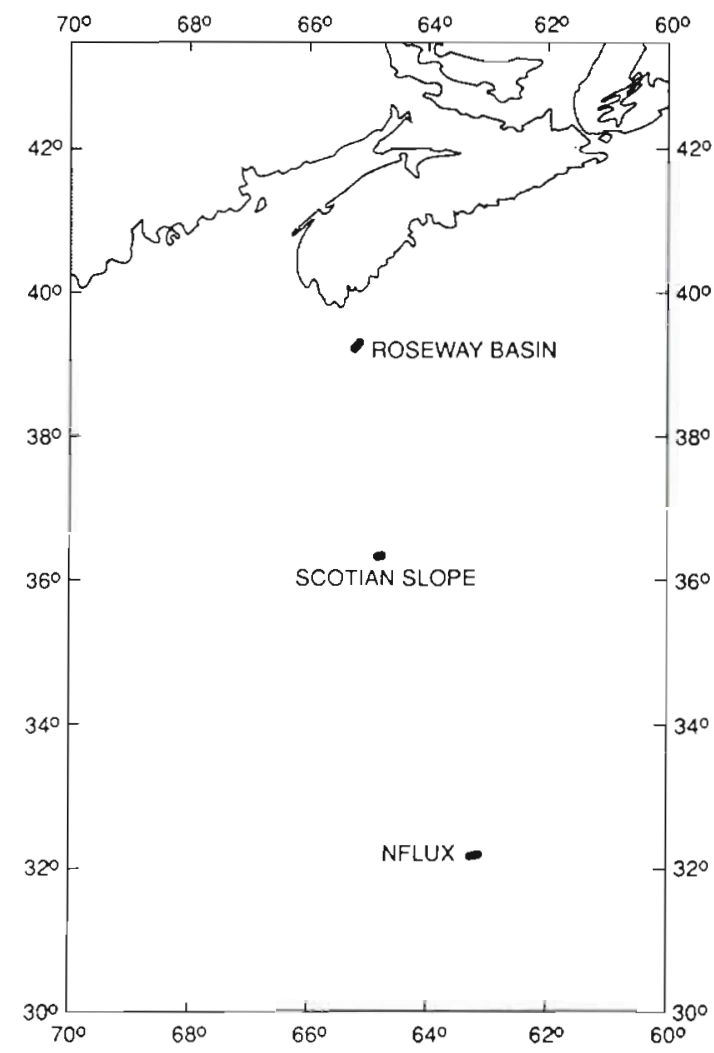

Fig. 1. Location of 3 stations sampled for DOC analysis by high temperature catalytic oxidation. This transect of 3 stations was chosen to encompass as wide a range of surface waters as possible, i.e. from Roseway Basin on the Scotian shelf to the seaward edge of the Scotian Slope and finally to NFLUX in the western Sargasso Sea

taken daily at 08:00 to 09:00 h (AST) for 2 to $4 \mathrm{~d}$ at each station and a deep rosette cast (taking water from depths of 300 to $4000 \mathrm{~m}$ ) was sampled at NFLUX.

Samples were transferred into $250 \mathrm{ml}$ polyethylene bottles with polyethylene caps. In laboratory tests we found that polyethylene bottles did not introduce contamination provided that they were soaked overnight in $0.1 \mathrm{~N} \mathrm{HCl}$, rinsed 3 times in distilled water and filled with Sargasso surface water. The precleaned bottles were then stored at room temperature for 3 mo and emptied just prior to drawing samples from the Niskin bottles. During sampling, we followed the recommendations of Peltzer et al. (unpubl.); care was taken that during each sample rinse and draw, seawater was allowed to flow directly from the Niskin stopcock into a precleaned polyethylene bottle without tubing and without the stopcock touching the bottle. In addition, DOC samples were drawn immediately after sampling for oxygen, but before all other sampling, to reduce the chance of contamination.

In order to test for contamination during filtration, we took $100 \mathrm{ml}$ aliquots from the sample bottles to be 
compared with an unfiltered aliquot. Samples were filtered through $0.2 \mu \mathrm{m}$ or $0.4 \mu \mathrm{m}$ polycarbonate membranes (Nuclepore) or through fiberglass filters (Whatman GFF) that had been precombusted for $2 \mathrm{~h}$ at $450^{\circ} \mathrm{C}$. Filtered or unfiltered seawater was then transferred as $5 \mathrm{ml}$ aliquots into $10 \mathrm{ml}$ pyrex test tubes that had been cleaned using a method similar to that of E. T. Peltzer (unpubl.). The tubes were soaked overnight in $2 \% \mathrm{NaOH}$, rinsed 5 times in distilled water and dried in an oven at $80^{\circ} \mathrm{C}$. Once samples were dispensed into the tubes, they were acidified (to $\mathrm{pH}$ 1.6) with 1 drop of concentrated $\mathrm{H}_{3} \mathrm{PO}_{4}$ for shipboard analysis by high temperature catalytic oxidation within $2 \mathrm{~h}$ of collection. Acidified aliquots were also stored for 3 wk in precleaned $20 \mathrm{ml}$ Pyrex tubes with Teflon-lined screw caps before analysis on land. All samples were stored in the dark at $5^{\circ} \mathrm{C}$ and were not frozen.

Temperature, salinity, chlorophyll and oxygen. During deployment of the Niskin rosette, water temperature and salinity were monitored at $2 \mathrm{~m}$ intervals by the CTD (Guildline). Samples were taken from each Niskin bottle on the rosette for the analysis of chlorophyll as bulk chlorophyll a on Whatman GFF filters (Holm-Hansen et al. 1965) and for the analysis of dissolved oxygen by automated Winkler titration (Williams \& Jenkinson 1982).

Dissolved organic carbon. For sample analysis, we used a commercially available Ionics Model 1500 Carbon Analyzer (Watertown, MA, USA) equipped with a ceramic slider auto-injection valve and auto-sampler. We employed a sample sequence of repeatedly injecting 2 acidified aliquots of seawater followed by 2 injections of acidified distilled water into the oxidation furnace to avoid rapid salt build-up on the catalyst. At the beginning of each sample analysis, $5 \mathrm{ml}$ of acidified water in the pyrex auto-sampler tube was initially sparged with $\mathrm{CO}_{2}$-free oxygen for $90 \mathrm{~s}$ to remove inorganic carbon. Subsequent tests demonstrated that $90 \mathrm{~s}$ of sparging was less than the minimum of $3 \mathrm{~min}$ required to completely remove inorganic carbon. The sparging of samples for less than 3 min resulted in up to $140 \mu \mathrm{M}$ of excess $\mathrm{C}$. The acidified and sparged sample was then aspirated into a teflon sample loop and $80 \mu \mathrm{l}$ were drop-injected onto a platinum catalyst in a quartz tube. The furnace design was identical to that of Peltzer et al. (1991) with 'pillows' of platinum gauze catalyst fitted tightly into the portion of the quartz tube inside the furnace. Effluent from the rapid combustion of the $80 \mu \mathrm{l}$ drop at $800^{\circ} \mathrm{C}$ was swept by the carrier gas $\left(\mathrm{CO}_{2}\right.$-free oxygen) through a series of traps before entering a Horiba non-dispersive infrared (NDIR) analyzer. After passing through a water separator, the effluent passed through a tin-shot trap to remove $\mathrm{HCl}$ gas, a pyrex $\mathrm{U}$ tube at $1^{\circ} \mathrm{C}$ and a $\mathrm{Mg}\left(\mathrm{ClO}_{4}\right)_{2}$ trap to remove water vapour, and a particle filter (Balston type 9900-05-BK) to remove sea-salt and phosphoric acid aerosols, before entering the NDIR analyzer. The signal generated by the NDIR detection of $\mathrm{CO}_{2}$ was quantified as peak area on a Hewlett Packard model 3396 integrator.

Integration of peak area was hampered by NDIR baseline noise which contributed to the variability of individual measurements. The Horiba NDIR has a relatively noisy baseline in the signal range needed to measure DOC in seawater (Peltzer et al. unpubl.) and an increase in baseline noise at sea was primarily related to the sensitivity of the NDIR to motion. As a result, the analytical error on station was typically between 3 and $12 \%$, compared with 2 to $5 \%$ on land. We did not analyze samples while the ship was underway between stations because analytical errors became unacceptably high (18 to $29 \%$ ).

The concentration of DOC in each sample was determined from standard curves produced every day by the analysis of glucose added to photo-oxidized seawater (Fig. 2). We chose photo-oxidized seawater as our analytical matrix rather than oxygen-minimum water (as recommended by Peltzer et al. unpubl.) because it resulted in the most stable and reproducible linear standard curves from day to day. At sea, slopes of the standard curves generally changed by 7 to $12 \%$ from day to day, but care had to be taken to avoid the longterm accumulation of salt on the catalyst. This salt buildup took place despite the repeated injection of acidified distilled water and, over time, caused relatively large $(20$ to $50 \%)$ variations in curve slopes. In addition, salt accumulation tended to increase the $Y$-axis offset of curves and the apparent concentration of DOC in photo-oxidized seawater (determined by extrapolation of a curve to the $X$-axis intercept; Fig. 2).

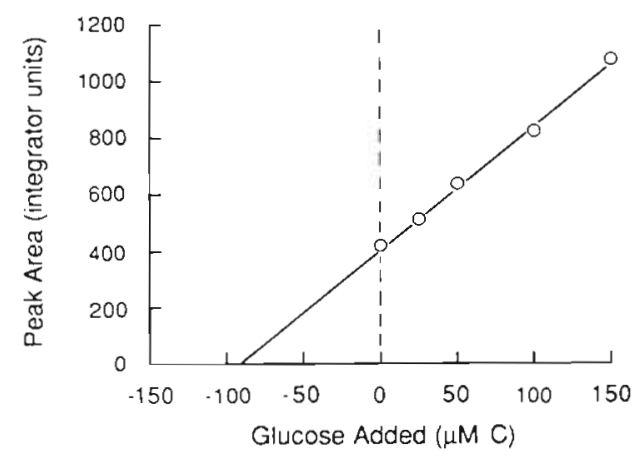

Fig. 2. Calibration curve from the analysis of DOC standards produced by the addition of 4 dissolved glucose concentrations to photo-oxidized Sargasso surface water. The seawater was stored at room temperature for 11 mo before photooxidation and standards were sparged for $3 \mathrm{~min}$ at $\mathrm{pH} 1.6$ before analysis. The linear fit to the analyses is $y=4.68 x+$ $413.6(r=0.9979)$. The $X$-axis intercept $(-88.4 \mu \mathrm{MC})$ is an estimate of DOC concentration in the photo-oxidized seawater; standard curve slopes varied by 7 to $12 \%$ from day to day 
The analysis of standard additions of glucose to distilled water resulted in an analytical blank of 35 to 40 $\mu \mathrm{M} \mathrm{C}$ when curves were extrapolated back to $X$-axis intercepts. This was not a true instrument blank because it included the organic carbon that was oxidized in distilled water. In addition, the analysis of glucose standards in seawater tended to decrease the slopes of curves compared to those produced from the same standard additions to distilled water (C. Brussaard, M. H. C. Stoll, J. Hegeman, J. Schijf \& H. J. W. de Baar unpubl.). This means that the instrument blank can only be determined from analysis of standard additions to a seawater matrix. As a result, it will not be possible to report an instrument blank for the Ionics (or any other) instrument based on high temperature catalytic oxidation until isotope studies have been carried out to determine the fate of organic material oxidized at high temperature (Hedges 1992). Given this current state of DOC analysis, we have reported all of our results without subtracting an instrument blank.

\section{RESULTS}

\section{Filtration and sample storage}

The concentration of DOC in seawater is low and contamination of samples during handling (Wangersky 1975) was a possibility in both our shipboard and shore-based work. By following some, if not all, the recommendations of Peltzer et al. (unpubl.), we were able to avoid the more obvious sources of contamination during sample handling. However, given that filtration was a major potential source of contamination (Peltzer et al. unpubl.), we decided to compare DOC measurements in unfiltered versus filtered samples before venturing to interpret DOC profiles at the 3 stations. We found that filtration of either shallow or deep water samples through polycarbonate membranes $(0.2$ or $0.4 \mu \mathrm{m}$ Nuclepore) resulted in variable additions of up to $22 \%$ to measured DOC concentrations. In contrast, precombusted fiberglass filters (Whatman GFF) had a relatively small effect (less than an analytical error of 3 to $12 \%$ ) on DOC measurements in the upper $100 \mathrm{~m}$. This was probably related to both the absence of contamination and the fact that particulate organic carbon was less than $10 \%$ of the total organic carbon (B. Irwin unpubl.). In deep water, however, filtration through precombusted fiberglass increased DOC concentration by as much as $18 \%$ of a given measurement. We do not know why organic carbon was consistently added to deep water samples by filtration but, on the basis of our results, we decided to use measurements from fiberglass-filtered samples for the interpretation of DOC profiles in the upper $100 \mathrm{~m}$ and measurements from unfiltered samples for the interpretation of profiles from deeper water.

Shore-based measurements of DOC in acidified samples stored a $5^{\circ} \mathrm{C}$ in the dark yielded profiles that were within the analytical error of shipboard determinations. Good agreement between fresh and stored samples was only apparent when the stored samples did not come in contact with the teflon-lined caps of the sample tubes, which are a major source of contamination (E. T. Peltzer unpubl.).

\section{Shallow and deep DOC profiles}

Over $2 \mathrm{~d}$, the vertical distribution of DOC was similar at Roseway Basin and the Slope, with a peak of DOC concentration at $20 \mathrm{~m}$ (Fig. 3). This peak was not main-
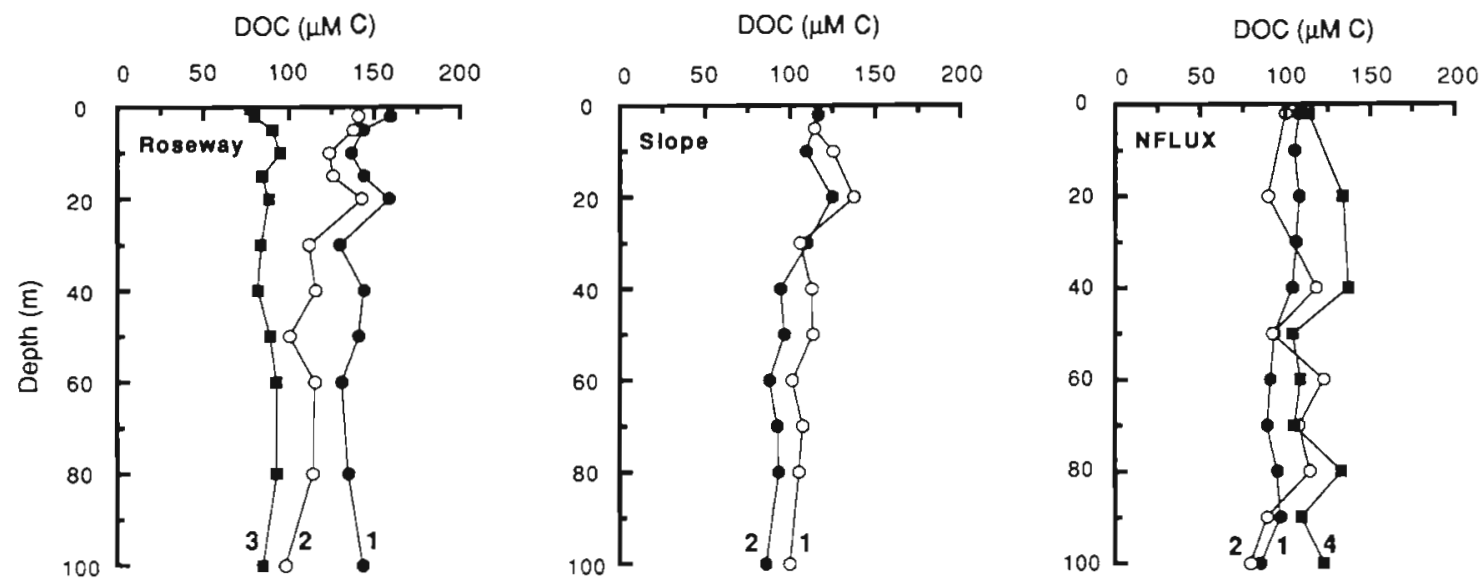

Fig. 3. Profiles of DOC measured every $24 \mathrm{~h}$ for $3 \mathrm{~d}$ at Roseway Basin, for $2 \mathrm{~d}$ at the Scotian Slope and for $4 \mathrm{~d}$ at NFLUX (day numbers at the bottom of profiles). The Day 3 and Day 4 profiles at NFLUX and the Day 3 profile at Roseway Basin were determined from land-based measurements; the remainder of the profiles were determined from measurements made on station The Day 3 profile from NFLUX (which was simlar to the Day 2 profile) has been omitted for clarity 

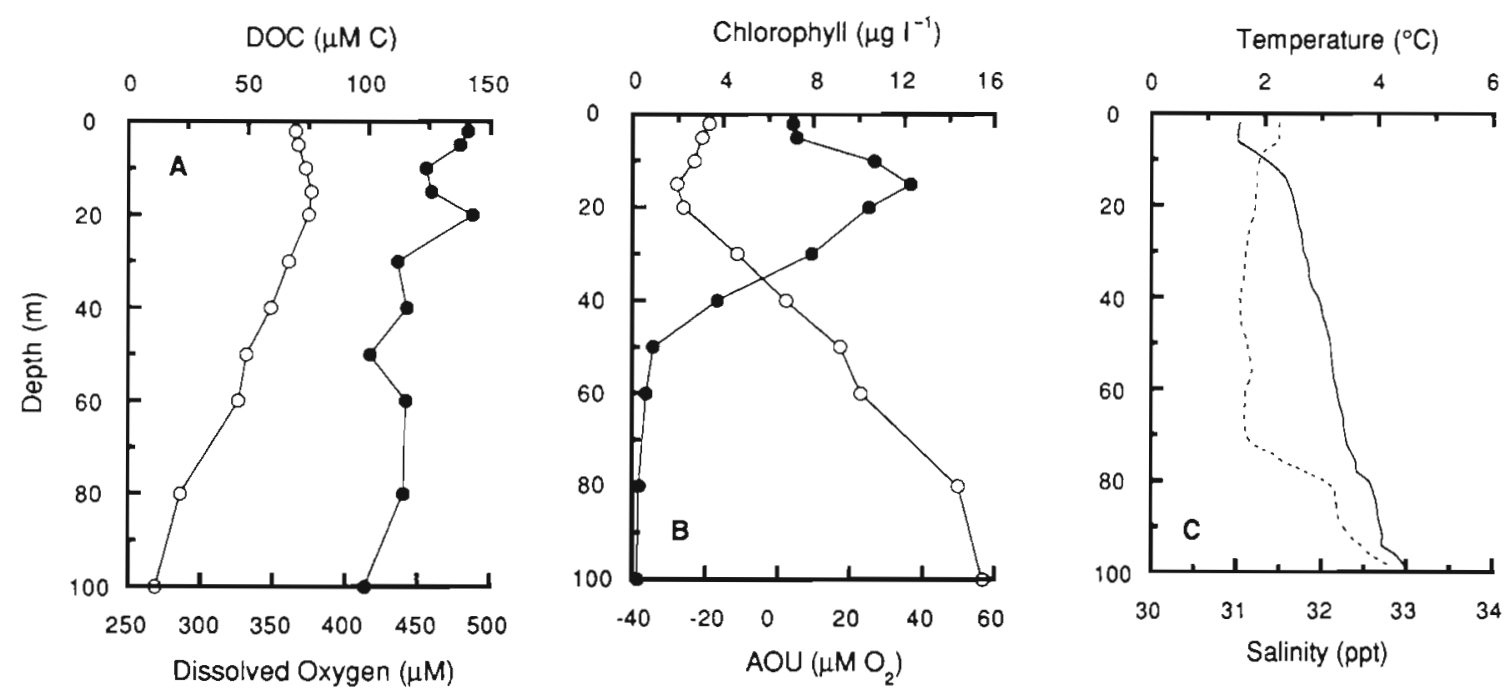

Fig. 4. (A) DOC $(\bullet)$ and dissolved oxygen (O); (B) chlorophyll $(\bullet)$ and AOU (O); (C) temperature (-.---) and salinity (- - . All of these profiles of the upper $100 \mathrm{~m}$ were determined on Day 2 at Roseway Basin

tained from Day 2 to Day 3 at Roseway, when DOC concentrations were considerably lower throughout the water column. At NFLUX (Fig. 3), there was no consistent structure apparent in any of the DOC profiles over $4 \mathrm{~d}$. In addition, the variations from day to day at Roseway and NFLUX were often greater than the differences observed between stations. Given these variations, and the possibility that DOC could be rapidly degraded (Kirchman et al. 1991), there may well have been diurnal variations in the DOC profiles. We could not explore this possibility because of the limited number of samples that could be analyzed on station. Instead, we tried to reduce the possible effects of diurnal variations by collecting samples at the same time of day (from CTD casts taken between 08:00 and 09:00 h AST).
In Roseway Basin, cold (ca $2{ }^{\circ} \mathrm{C}$ ) water in the mixed layer typically extended down to a depth of about $70 \mathrm{~m}$ and was underlain by slightly warmer $\left(2\right.$ to $\left.4{ }^{\circ} \mathrm{C}\right)$ water intruding from the seaward edge of the Scotian Shelf (E. P. W. Horne unpubl.). High chlorophyll concentrations in the mixed layer were inversely related to $\mathrm{AOU}$ (Fig. 4B), i.e. a chlorophyll maximum at $15 \mathrm{~m}$ was associated with an AOU minimum. The peak of DOC at $20 \mathrm{~m}$ (Fig. 4A) was associated with the chlorophyll maximum and AOU minimum, but was still located $5 \mathrm{~m}$ below the chlorophyll maximum. DOC exhibited a positive linear correlation (Fig. 5A; Table 1) with the relatively high chlorophyll concentrations in Roseway Basin; it was also inversely correlated with $\mathrm{AOU}$ and chlorophyll (Fig. 5B, C, Table 1).

Table 1 Model I and model II linear regressions of DOC with chlorophyll, DOC with AOU, and AOU with chlorophyll from profiles down to $100 \mathrm{~m}$ at 3 stations in the $\mathrm{N}$. Atlantic. The linear fits of DOC and AOU from deep water samples at the open ocean station (NFLUX) are shown for reference. The slope from a model II regression is equivalent to the model I slope (Fig. 5) divided by the correlation coefficient (Laws \& Archie 1981)

\begin{tabular}{|llccc|}
\hline Location & \multicolumn{1}{c}{$\begin{array}{c}\text { Variables } \\
(X ; Y)\end{array}$} & $\begin{array}{c}\text { Slope } \\
\text { (model I) }\end{array}$ & $\begin{array}{c}\text { Slope } \\
\text { (model II) }\end{array}$ & $\begin{array}{c}\text { Correlation } \\
\text { coefficient (r) } \\
\text { (model I) }\end{array}$ \\
\hline Roseway (Day 2) & Chlorophyll; DOC & 2.27 & 0.688 \\
& AOU; DOC & -0.38 & 3.30 & 0.754 \\
& Chlorophyll; AOU & -4.36 & -0.50 & 0.957 \\
Slope (Day 1) & Chlorophyll; DOC & 8.45 & -4.56 & 0.796 \\
& AOU; DOC & -2.03 & -3.18 & 0.637 \\
NFLUX (Day 4, shallow) & Chlorophyll; AOU & -3.02 & -3.96 & 0.762 \\
& Chlorophyll; DOC & 8.60 & 39.63 & 0.217 \\
& AOU; DOC & -1.94 & -3.89 & 0.499 \\
NFLUX (Day 4, deep) & Chlorophyll; AOU & 9.26 & 20.58 & 0.450 \\
& AOU; DOC & -0.21 & -0.25 & 0.841 \\
\hline
\end{tabular}



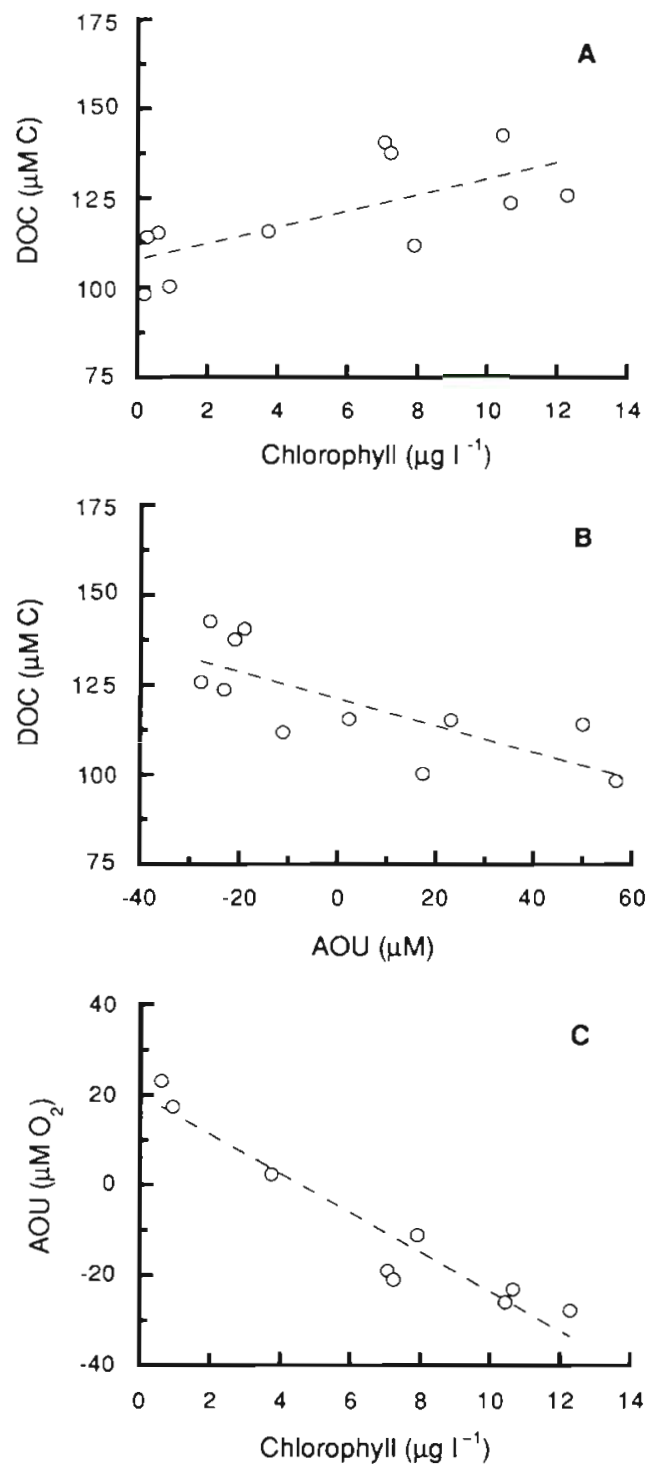

Fig. 5. Model I linear best fits of (A) DOC with chlorophyll (B) DOC with AOU and (C) AOU with chlorophyll in the upper $100 \mathrm{~m}$ on Day 2 at Roseway Basin. The model I and II slopes and correlation coefficients dre listed in Table 1

We employed geometric mean models I and II (as outlined by Laws \& Archie 1981) to obtain linear correlations between the dependent $(Y)$ and independent $(X)$ variables. The model If regression takes into account the measurement errors in both $Y$ and $X$; the more commonly utilized model I regression takes only the error in $X$ into account. The scatter of data points around best fits (Fig. 5A, B) could be related to the higher $( \pm 3$ to $12 \%$ ) errors of DOC analysis at sea. For example, when error envelopes of $\pm 12 \%$ around a mean DOC concentration of $240.1 \pm 30.3 \mu \mathrm{M} \mathrm{C}$ were superimposed on Fig. 5A, B with slopes equivalent to the lines of best fit (Table 1), they included all of the data points. In contrast, the inverse correlation of $\mathrm{AOU}$ with chlorophyll (Fig. 5C; Table 1) was relatively strong and may have been related to lower analytical errors in the case of oxygen $( \pm 1 \%)$ and chlorophyll $( \pm 0.8 \%)$ analyses.

At this point, however, it is important to remember that the scatter apparent in Fig. 5A, B could be related to a combination of processes involved in the production of DOC. For example, if DOC was produced by actively growing phytoplankton in combination with the slow solubilization of particulate organic carbon (POC), there would be no simple relationship between DOC, AOU and chlorophyll. As a result, the consistent and reproducible variations apparent in the upper 20 to $30 \mathrm{~m}$ of the DOC profiles (Fig. 3) would not necessarily be related to linear correlations obtained over the complete $100 \mathrm{~m}$ (Fig. 5).

At the Scotian Slope (Fig, 6C), the mixed layer was far warmer (with a temperature of about $12.8^{\circ} \mathrm{C}$ ) than the coastal water at Roseway Basin and extended down to about $60 \mathrm{~m}$. Chlorophyll concentrations (Fig) $6 \mathrm{~B}$ ) were also 3 to 4 times lower than those found at Roseway Basin (Fig. 5B). As with coastal water, DOC at the Slope was inversely correlated with $\mathrm{AOU}$ and positively correlated with chlorophyll (Fig. 6A, B; Table 1); a weaker correlation of AOU with chlorophyll (Table 1) was probably related to a weaker chlorophyll maximum at $20 \mathrm{~m}$, although chlorophyll was generally higher above $60 \mathrm{~m}$ than below (Fig. 6B). At NFLUX chlorophyll, AOU and DOC followed no recognizable pattern with depth in the upper $100 \mathrm{~m}$ (Figs. $3 \& 7$ ) In addition, there were poor correlations between DOC, AOU and chlorophyll (Fig. 7; Table 1), and low chlorophyll concentrations (Fig. 7A) were associated with a mixed layer (at a temperature of 18.8 to $19.2^{\circ} \mathrm{C}$ ) that extended down to about $50 \mathrm{~m}$.

Results from the deep rosette cast at NFLUX exhibited a clear inverse relationship between AOU and DOC over depths of 300 to $4000 \mathrm{~m}$ (Fig. 8A). This inverse relationship was linear (Fig. 8B; Table 1), but a slope of -0.21 or -0.25 was less than expected, given the slope of -0.56 recorded at $45^{\circ} \mathrm{N}$ by Peltzer et al. (unpubl.) in the North Atlantic and the slope of -0.8 recorded by Sugimura \& Suzuki (1988) in the western Pacific. The molar relationship between AOU and DOC should yield a slope of -0.77 if organic matter of average marine composition (Redfield et al. 1963) is being oxidized and samples are drawn from the same water mass (Toggweiler 1989). However, Peltzer et al. (unpubl.) have already pointed out that the hydrography of the North Atlantic Ocean is complex, invalidating the single water mass assumption. If this complexity is true of water masses down to $4000 \mathrm{~m}$, it would certainly be true of those found in the upper $100 \mathrm{~m}$ and could explain the variation in slopes of AOU versus DOC in surface waters (Table 1). 

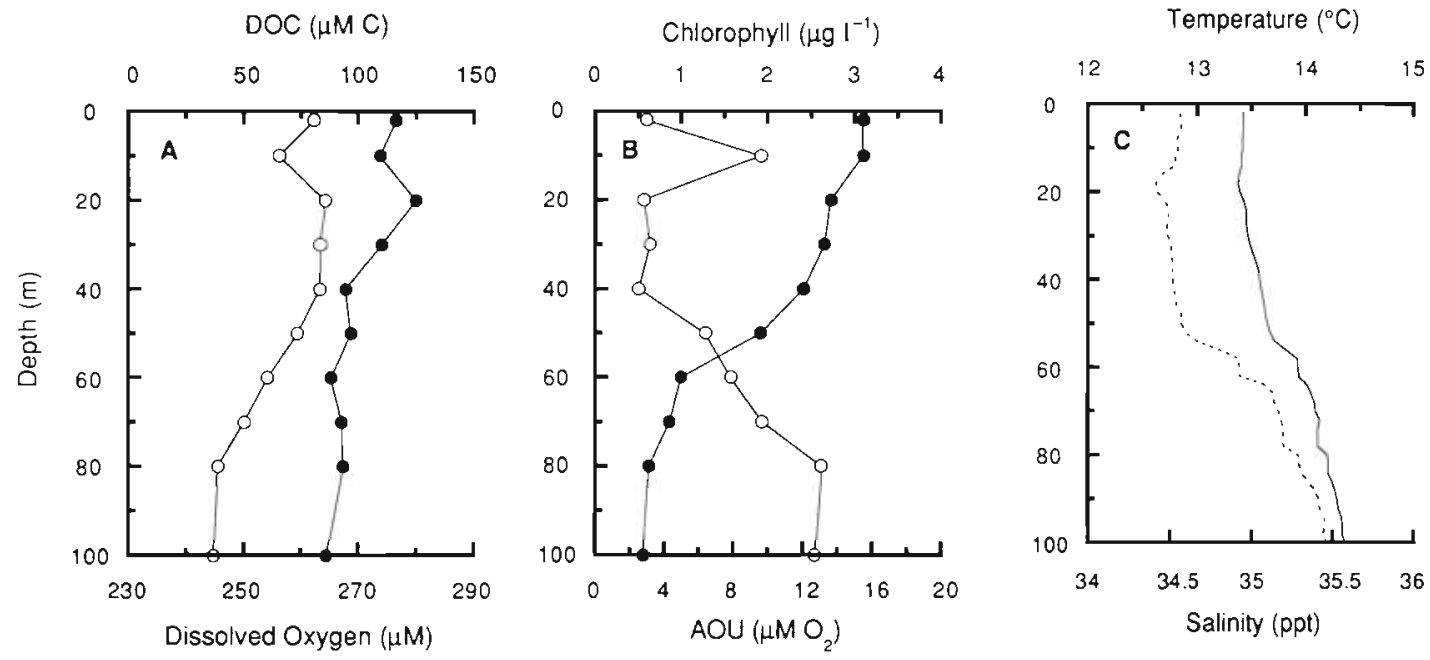

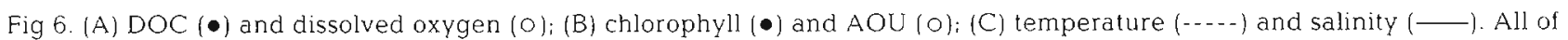
these profiles of the upper $100 \mathrm{~m}$ were determined on Day 1 at the Scotian Slope
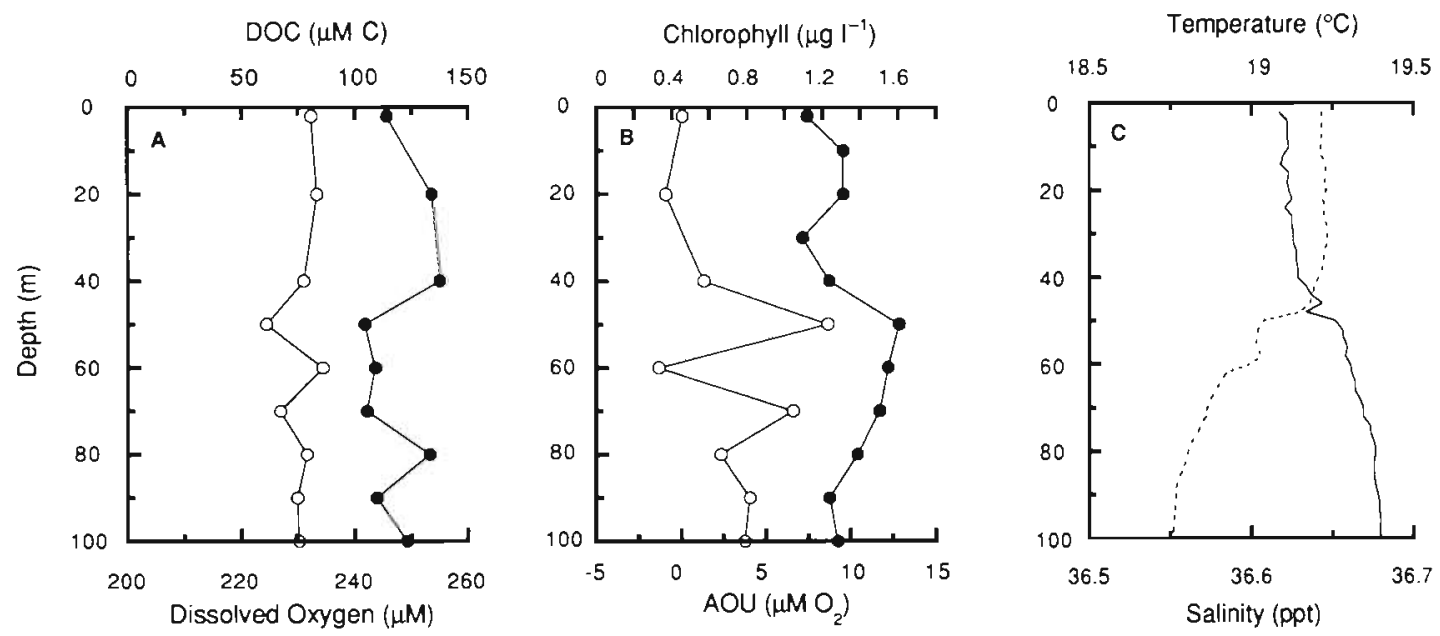

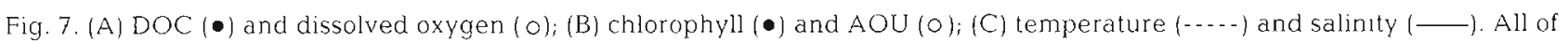
these profiles of the upper $100 \mathrm{~m}$ were determined on Day 4 at NFLUX

Fig 8. (A) Inverse relationship of DOC ( $\bullet$ ) and AOU (O) from 300 to $4000 \mathrm{~m}$ at NFLUX on Day 4. (B) Corresponding linear correlation of DOC with AOU llisted in Table 1)
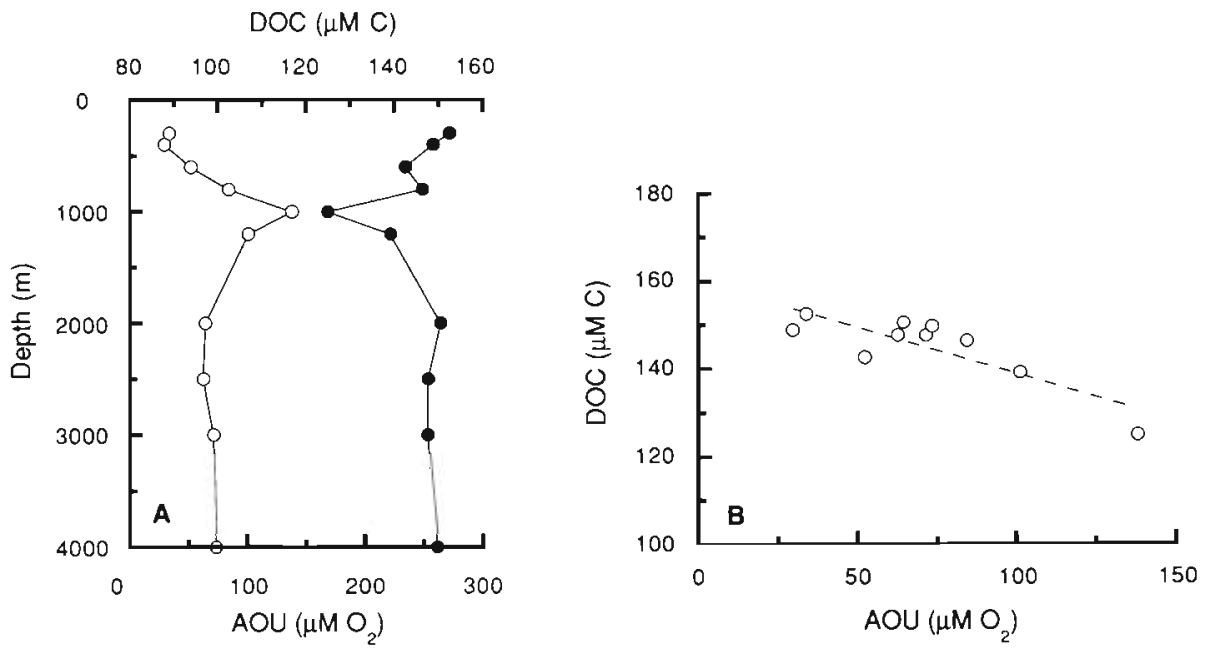


\section{DISCUSSION}

We found that it was possible to obtain consistent and reproducible DOC profiles (Fig. 3) when seawater sampled to a depth of $100 \mathrm{~m}$ was analyzed by high temperature catalytic oxidation. Our range of DOC concentrations overlapped previous measurements obtained from the North Atlantic Ocean with a similar instrument (Peltzer et al. unpubl.) and was within the very wide range of values obtained from the analysis of aged seawater by other high temperature catalytic oxidation instruments (Hedges 1992). Given the present state of DOC analysis, it is clear that our data are not the final word on DOC measurement in surface waters. More definitive results await the determination of a true instrument blank (Hedges 1992) but, even with these limitations, our data suggest that the additional or 'new' DOC revealed by high temperature catalytic oxidation (Williams \& Druffel 1988, Druffel et al. 1989) is biologically labile. This lability was evident in the positive correlation of DOC with chlorophyll (Fig. 5A; Table 1) and the inverse correlation of DOC with AOU (Fig. 5B; Table 1), where AOU was also inversely correlated with chlorophyll (Fig 5C; Table 1).

The concept of apparent oxygen utilization (Broecker \& Peng 1982) was originally developed to facilitate stoichiometric calculations of carbon degradation and oxygen utilization over long time scales in stable, deep-ocean water masses. It is unlikely that water masses in the upper $100 \mathrm{~m}$ remained stable, and photosynthesis produced oxygen resulting in negative values for $\mathrm{AOU}$ (Figs, 4, $5 \& 7$ ). These 2 factors are significant additions to an originally simple concept, and we were surprised that reasonably strong correlations were obtained between chlorophyll, AOU and DOC at Roseway Basin and the Slope (Fig. 5; Table 1). Even though the correlations could not be interpreted simply, they are still good evidence for the biological lability and net oxidation of DOC

To our knowledge, these data are the first to demonstrate that the lability of DOC in the upper $100 \mathrm{~m}$ of ocean is related to such standard biological parameters as chlorophyll and AOU A positive correlation between chlorophyll and the DOC measured by high temperature oxidation has been observed in phytoplankton cultures (Sharp 1973, W. Chen \& P J. Wangersky unpubl.); until now, there has been no similar evidence from natural waters. There is also little doubt that the DOC revealed by high temperature catalytic oxidation is labile over the times required to develop DOC and AOU gradients to depths of thousands of meters (Sugimura \& Suzuki 1988, Druffel et al. 1989, Peltzer et al. 1991). We can now add that our data support the results of Kirchman et al. (1991), suggesting that a significant fraction of DOC could be respired to
$\mathrm{CO}_{2}$ in the upper ocean before more resistant fractions are incorporated into the longer-term consumption of DOC at greater depth.

Even though DOC may be broken down by biological processes near the ocean surface, the everchanging hydrography of the mixed layer cannot be ignored. By Day 3, the consistent DOC profiles measured during Days 1 and 2 at Roseway Basin were not maintained (Fig. 3) and, at NFLUX, the DOC profiles over $4 \mathrm{~d}$ were a good deal less than consistent. The day-to-day variations in DOC observed at both stations (Fig. 3) were too large to be attributed to variations in the primary production of organic carbon (Peltzer et al. unpubl.). Instead, it is more likely that these variations were related to horizontal advection (E. P. W. Horne unpubl.) and the patchiness of biological activity in weakly stratified waters (Figs. 4 \& 7). Despite our choice of the 3 stations to cover a wide range of chlorophyll concentrations in the mixed layer (Figs. 4, 6 \& 7), the combined effects of advection and patchiness were most evident in large day-to-day variations in DOC profiles at both Roseway Basin and NFLUX. These variations were as large as $40 \mu \mathrm{M} \mathrm{C}$ (Fig. 3) and were certainly greater than those related to analytical errors or predicted rates of DOC consumption (Kirchman et al. 1991); they were even greater than the variations observed between stations. As a result, it is unlikely that utilization of one or several DOC profiles will allow carbon flux in the upper ocean to be modelled accurately. Instead, DOC measurements from the mixed layer must be presented along with the biological and physical processes contributing to the production and consumption of DOC and its coagulation as a colloidsized pool of organic carbon (Johnson \& Kepkay 1992).

The slopes of DOC against AOU in the upper $100 \mathrm{~m}$ (Fig 5; Table 1) were often greater than the slope of -0.77 predicted from the oxidation of organic matter of average marine composition (Redfield et al. 1963). Stronger inverse slopes suggest that more DOC was removed from the upper $100 \mathrm{~m}$ than could be explained by apparent oxygen utilization. This apparent enhancement of DOC removal could have been related to photochemical degradation (Mopper et al. 1991), oxygen production by photosynthesis or changing water masses due to advection, but coagulation and particle aggregation (Kepkay \& Johnson 1989. Jackson 1990, Johnson \& Kepkay 1992) were additional factors that could not be ignored. Large numbers of sub-micron particles were found as small aggregates in the upper $100 \mathrm{~m}$ at all 3 stations (M. L. Wells unpubl.). This raises the possibility that labile DOC was transported as aggregates to deeper waters before being oxidized further.

Finally, while results from the deep rosette cast at NFLUX demonstrated a clear inverse relationship 
between AOU and DOC (Fig. 8A), slopes of -0.21 or -0.25 for the linear correlation of DOC with AOU (Fig. 8B; Table 1) were less than expected (Peltzer et al. 1991). This, again, may be a function of complex hydrography, but no samples were taken from intermediate depths to verify the possibility. However, even with this lack of information, the results from NFLUX suggest that a better understanding of the physical and biological processes contributing to the transport of carbon into deeper water is required to interpret the significance of DOC and AOU profiles in the North Atlantic Ocean.

Acknowledgements. We thank Bill Li, Peter Schwinghamer, David Burdige and Glenn Harrison for many useful comments. We also thank Frank Hoek and Catherine Smith (of Ionics) for their help during initial set up of our high temperature catalytic oxidation instrument.

\section{LITERATURE CITED}

Broecker, W. S., Peng, T.-H. (1982). Tracers in the sea. Lamont-Doherty Geological Observatory, Columbia University, Palisades, New York, p. 131

Craig, $H$. (1971). The deep metabolism: $\mathrm{O}_{2}$ consumption in abyssal ocean water. J. geophys. Res. 76(21): 5133-5139

Ducklow, H. W., Fasham, M. J. R., Vezina, A. F. (1989). Derivation and analysis of flow networks for open ocean plankton systems. In: Wulff, F., Field, J. G., Mann, K. H. (eds.) Coastal and estuarine studies, Vol. 32. SpringerVerlag, New York, p. 159-205

Druffel, E. R. M., Williams, P. M., Suzuki, Y (1989). Concentrations and radiocarbon signatures of dissolved organic matter in the Pacific Ocean. Geophys. Res. Lett. 16: 991-994

Hedges, J I. (1987). Organic matter in sea water Nature. Lond. 330: 205-206

Hedges, J. I. (1992). Preliminary report from a workshop on The measurement of dissolved organic carbon and nitrogen in natural waters. Battelle Seattle Conference Center, Seattle, Washington

Holm-Hansen, O., Lorenzen, C. J., Holmes, R. W., Strickland, J. D. H. (1965). Fluorometric determination of chlorophyll J. Cons. perm. int. Explor. Mer 30: 3-15

Jackson, G. A. (1988). Implications of high dissolved organic matter concentrations for oceanographic properties and processes. Oceanography 1: 28-22

Jackson. G. A. (1990). A model of the formation of marine algal flocs by physical coagulation processes. Deep Sea Res. 37: 1197-1211

This article was presented by T. Platt, Dartmouth, N. S., Canada
Johnson, B. D., Kepkay, P. E. (1992). Colloid transport and bacterial utilization of oceanic DOC. Deep Sea Res. (in press)

Kepkay, P. E., Johnson, B. D. (1989). Coagulation on bubbles allows the microbial respiration of oceanic dissolved organic carbon. Nature. Lond. 385: 63-65

Kepkay, P. E., Harrison, W. G., Irwin, B. (1990). Surface coagulation, microbial respiration and primary production in the Sargasso Sea. Deep Sea Res. 37: 145-155

Kirchman, D. L., Suzuki, Y., Garside, C., Ducklow, H. W. (1991). Bacterial oxidation of dissolved organic carbon in the north Atlantic Ocean during the spring bloom. Nature, Lond. 352: 612-614

Laws, E. A., Archie, J. W. (1981). Appropriate use of regression analysis in marine biology. Mar. Biol. 65: 13-16

Longhurst, A. R., Bedo, A., Harrison, W. G., Head, E. J. H., Horne, E. P. W., Irwin, B., Morales, C. (1989). NFLUX: a test of vertical nitrogen flux by diel migrant biota. Deep Sea Res. 36: 1705-1719

Mopper, K., Zhou, X. L., Kieber, R. J., Kieber, D. J., Sikorski, R. J., Jones, R. D. (1991). Photochemical degradation of dissolved organic carbon and its impact on the oceanic carbon cycle. Nature, Lond. 353: 60-62

Redfield, A. C. (1958). The biological control of chemical factors in the environment. Am. Sci. 46: 205-221

Redfield, A. C., Ketchum, B. H., Richards, F. A. (1963). The influence of organisms on the composition of seawater In: Hill, M. N. (ed.) The sea, Vol. 2. John Wiley and Sons, New York, p. 26-77

Sharp, J. H. (1973). Total organic carbon in seawater comparison of measurements using persulfate oxidation and high temperature combustion. Mar Chem. 1: $211-229$

Sugimura, Y., Suzuki, Y (1988). A high temperature catalytic oxidation method for the determination of non-volatile dissolved organic carbon in seawater by direct injection of a liquid sample. Mar. Chem. 24: 105-131

Toggweiler, J. R. (1989). Is the downward dissolved organic matter (DOM) flux important in carbon transport? In: Berger, W. H., Smetacek, V. S., Wefer, G. (eds.) Productivity of the ocean; past and present. John Wiley and Sons, New York, p. 65-83

Toggweiler, J. R. (1990). Diving into the organic soup. Nature, Lond. 345: 203-204

Wangersky, P. J. (1975). Measurement of organic carbon in seawater In: Gibb, T R. P. (ed.) Analytical methods in oceanography. Am. Chem. Soc., Washington, D.C., p. $148-162$

Williams, P. J. LeB., Jenkinson, N. W. (1982). A transportable, microprocessor-controlled Winkler titration suitable for field station and ship board use. Limnol. Oceanogr. 27 : 576-584

Williams, P. M., Druffel, E. R. M. (1988). Dissolved organic matter in the ocean: comments on a controversy. Oceanogr. Mag. 1. 14-17

Manuscript first recelved: October 22, 1991

Revised version accepted: January 10, 1992 